\title{
Research on low carbon economic policy support system based on Web
}

\author{
Li Liu \\ Chongqing City Management College, Chongqing 401331, China \\ aaa@163.com
}

Keywords: Accounting, environmental accounting, low carbon economy, low carbon economy era.

\begin{abstract}
As a new branch of accounting the environmental accounting is produced in environmental governance from a variety of disciplines cross a frontier of Applied Science, it can reflect the enterprise production and management activities of the impact on the environment, promote the implementation of the strategy of sustainable development. This paper analyzes the current situation of environmental accounting in China, expounds the necessity of implementing environmental accounting in China, facing the development of environmental accounting problems, put forward reasonable suggestions, in order to promote the full implementation of environmental accounting in our country.
\end{abstract}

\section{Introduction}

With the development of economy, the increasing importance of environmental issues, human existence is remarkable attention, the establishment of ecological harmony of society has been widely recognized by the people. Low carbon economy is a new concept of development, low pollution, low emission, low energy consumption and economic models are increasingly popular, the development of low carbon economy has become the inevitable trend of the current global economic development[1]. Environmental accounting as an important component of a low carbon economy, the establishment of environmental accounting is not only conducive to the protection of ecological environment in China, comprehensively promote the construction of resource-saving society, but also conducive to the formation of low carbon environmental protection consciousness.

\section{Analysis of the Current Situation}

The study of the environment accounting originated in twentieth Century 70 in the United Kingdom, China began in twentieth Century 80's awareness of the environment accounting, 1992 Ge Jiashu to the western green accounting theory is introduced to the real writing a new chapter in environmental accounting research in china. For more than twenty years, Chinese scholars have made a lot of achievements to the research of environmental accounting[2].

The theory of environmental accounting. The goal of environmental accounting. The goal of environmental accounting and traditional accounting objectives, including basic and specific objectives, and environmental accounting's goal is to expand the traditional accounting objectives in the environmental information[3]. Can be expressed as the accounting subject to reasonable development and utilization of environmental resources, in the realization of their own economic benefits at the same time, the realization of common to improve social benefit and ecological benefit, provide the environment accounting information true and reliable.

Objects and elements of environmental accounting. Environmental accounting as a new branch of accounting, the accounting target is objectively reflect the whole process of accounting main body loss and compensation of environmental resources, provide reliable information for the sustainable development of economy [4].There are several viewpoints on environmental factors, including "three elements theory", "four elements theory", "five elements theory" and "six elements theory" four kinds of views. The author thinks, "six elements theory" to compare the complete objectively reflect the object of environmental accounting, including environmental assets, environmental liability, environmental rights, environmental cost, environmental income, and environmental profit. 
Accounting principles of environmental accounting. Accounting principles are the fundamental rules of guiding ideology and the measurement of accounting basis of accounting. The general principles of environmental accounting should not only follow the traditional accounting, and combined with the characteristics of environmental accounting itself, reflects its unique principles, including: social principle, the policy principle, the materiality principle, the principle of comparability, various valuation basis principles and compulsory principle. Environmental accounting must consider the impact on the ecological environment in the pursuit of economic efficiency of enterprises, both environmental benefits and social benefits, station performance evaluation in the whole social point of view, to make the changes and the development of enterprises is closely related to the environment, the enterprise active maintenance of environment construction, to improve the economic benefit and social benefit.

Environmental accounting assumption. Accounting hypothesis refers to the special economic environment, according to the practice and theory of the previous accounting, reasonable hypotheses or ideas to the field of accounting issues have not yet sure of [5].Environmental accounting hypothesis is the reasonable inference to the relationship between environment and accounting, is a prerequisite for the environmental accounting are. Therefore, the premise of environmental accounting assumption on the traditional accounting entity assumption, sustainable management and accounting period assumption also can be the monetary measurement assumption adjustment for multiple measurement models with the money metric based, supplemented by physical measurement or other measurement methods.

Recognition and measurement of environmental accounting elements. Environmental accounting elements confirmation standard have to combine the particularity of environmental accounting, On the basis of traditional accounting confirmation can impact on the utilization of resources and measure an accounting entity, especially in the natural environment of the costs involved in, such as profit and loss can reasonable confirmation. Accounting elements measurement includes measurement units, measurement attribute and measurement model, Environmental accounting can use monetary, physical, and other units, Choice in actual cost, replacement cost method and opportunity cost method, the recovery payments shall use valuation methods, investigation, evaluation, etc.

Environmental accounting information disclosure. In the era of low carbon economy, the environment is full disclosure of accounting information is one of the main purpose of establishing environmental accounting. To timely and appropriately environmental accounting information disclosure of accounting entity is the environmental protection department, the public, investors and other stakeholders on the need of environmental information, including environmental problems and their influence, the cost expenses incurred for environmental protection, environmental protection facilities investment, income and liabilities related to the environment, etc.

The necessity of the implementation of environmental accounting in our country. Carbon is one of the world economic development tendencies of the development of the economy.

Low carbon economy is the human survival and development provides a new idea, the essence of which is to reduce energy consumption and improve energy efficiency, the development of new energy, the pursuit of green GDP. The development of low carbon economy must begin from the positive environmental protection responsibility, and reasonable adjustment of economic structure and the low carbon economy can minimize energy consumption, realize "three lows" namely, low energy consumption, low pollution, low emission on the basis of economic growth. At present, the low-carbon economy has become the trend of world economic development.

Low carbon economy provides the development of environmental accounting theory and practice of space.Accounting for economic development, and with the development of economy and constantly improve its theoretical system and the accounting method, Low carbon economy era, need on an accounting entity in the economic activity of all kinds of energy consumption and the impact on the environment, damage, governance, such as timely reflect and supervise, it is for the development of environmental accounting in theory and practice, provides the realistic foundation. 
Low carbon economy era environment accounting is the necessary requirement of realizing economic sustainable growth.

The process of promoting the construction of ecological civilization in our country, the sustainable development of the economy not only requires the growth of the national economy stable, and the requirement of economic growth does not destroy the ecological balance, if it does not reduce the environmental quality of people live . Visible, enterprise in production and business operation only by constantly update ideas, innovation management, research and development for the development of new technology, new energy, adhere to the green production, green management can be in an impregnable position in the fierce competition. Therefore, enterprises as the main body of the low carbon economy development, must want to build, using feasible environment accounting, can the enterprise environment accounting and disclosure of accounting information, to achieve low carbon economy era the objective requirement of the sustainable economic growth and ecological environment protection.

Although our country's environmental accounting theory research and practice in western developed countries later, but from the point of view of the world economic development, scientific and rational use of natural resources, maintain a good ecological environment, promote low-carbon economy sustainable development become the urgent problems of mutual interest all over the world .Therefore, the implementation of environmental accounting is a low-carbon economy is an important part of the sustainable development strategy in the micro level.

\section{Problem Analysis to Development of Environmental Accounting}

The accounting entity is not enough emphasis on environmental accounting. In practical work, some enterprises only focus on immediate interests, regardless of the resource depletion and destruction of the ecological environment, in view of the environmental accounting in accounting subject is less, especially about the valuation of assets, environmental liabilities and environmental accounting income and expenditure of full and accurate reflect obviously not enough . Because our country accounting system to the enterprise environment accounting information disclosed or not there is no clear requirements, many companies did not attach enough importance to the implementation of environmental accounting.

The theoretical research on environmental accounting is not deep enough. Environmental protection supervision measures is still not perfect in China, and we didn't pay more attention to improve environmental accounting. It's late in our country, so the research on environmental accounting is not deep enough. Further more, it's still lack of systematic and originality, and more research still did not break away from the model of the overseas research results. There are more scholars to establish the theoretiacl system of environmental accounting in our country.

The information of environmental accounting is not enough. Envirinmental accounting disclosure is their work results. Beacuse of the accounting theory system and method is still not fully established, there are not unified in the confirmation, measurement, record in the environmental accounting elements, so the lack of method and standard on environmental accounting and information, which due to lack comparable caliber in the environmental cost and income disclosure. The State encourages enterprises voluntary disclose corporate environmental information, but the majority of enterprises is unwilling, and the disclosure report is not the norm. Some conpanies are considering their own interests, so some of environmental accounting information should be disclosed to the public's reservations. It will not be able to guarantee the authenticity and integrity of the environmental accounting disclosure information.

Constraint mechanism of environmantal accounting is not perfect. Although our country in December 26, 1989 promulgated the "environmental protection law", and the State Environmental Protection Administration in February 8, 2007 enacted the "Environmental Information Disclosure Measures (Trial)", in November 1, later 2011 the State Environmental Protection Department issued a" the Twelfth Five Year national environmental protection laws and regulations and environmental economic policy construction planning" and other legal provisions, but this is far from enough. There are a certain gap compared with the developed countries. Generally, business in accounting, they only 
consider their ownposition, and they are not willing to disclose environmental accounting information. Because of excessive exploitation of accounting information, such as natural resources waste and environmental monitoring exceeding the standard, the main economic activity may be forced to stop. Therefore, the country should establish and carry out laws for the implementation of environmental accounting. We should publish the irresponsible behavir of the sustainable economic development. The environmental protection departments of supervision and the pressure of public opinion can be rely on one department.

The shortage of environmantal accounting talents. Environmental accounting is a new multidisciplinary cross subject. We should solve the environmental problems in the accounting persperctive aspect that maintain the balance between the sustainable developmengt of the econmy and ecological environmant problems. We should possess higher comprehensive quality relate to economy, environment, accounting and other knowledge. Few scholars research environmantal accounting in China. There are a few people in practical work in high education, good management, interdiaciplinary, better environmantal accounting knowledge. That is a role not to be ignored on the implementation of environmental accounting.

\section{Conclusions}

The paper analyzes the current situation of environmental accounting in China, expounds the necessity of implementing environmental accounting in China, facing the development of environmental accounting problems, put forward reasonable suggestions, in order to promote the full implementation of environmental accounting in our country.

To sum up, the environmental accounting needs more research in our country. We should gain the support of national policy, accounting experts, and make more effort with enterprises and social accounting personnel as soon as possible. We propose the environmental accounting to promote the sustainable development of economy, ecological civization and achieve a win-win between the economical benefits and social benefits.

\section{References}

[1] X.Q. Xu: Green Accouting Development in China (Accounting Research, China 2007), p.32 -36. (In Chinese)

[2] D.C. Du: Research and Analysis on the Implementation of Green Accounting (Reformation and Stratrgy, China 2007), p.71-72. (In Chinese)

[3] X.D. Zhang, L. Ye: The Necessity and Measure on Green Accounting (Theory, China 2009)

[4] M.C. Li,: Study on the Development of Green Accounting in Low Carbon Economy Environment (Modern Accounting, China 2012)

[5] W.P. Xiao: Research on the Basic Theory of Environmental Accounting (Acconuting Monthly, China 2002) 